\title{
Türkçe eğitiminde eleştirel dinlemenin/izlemenin önemi ve yeri ${ }^{1}$
}

\section{Cafer CARKIT2}

\begin{abstract}
APA: Çarkıt, C. (2019). Türkçe eğitiminde eleştirel dinlemenin/izlemenin önemi ve yeri. RumeliDE
\end{abstract} Dil ve Edebiyat Araştırmaları Dergisi, (16), 180-193. DOI: 10.2900o/rumelide.618150

\section{$\ddot{\mathbf{O z}}$}

Toplumlar açısından hızlı değişimlerin yaşandığı dünyamızın her geçen gün daha karmaşık bir yapıya dönüşmesi, bilime yüklenen anlamın değişmesi ve bilgiye ulaşma yollarının boyut değiştirmesi inkâr edilemez bir gerçeklik olarak karşımızda durmaktadır. Buna bağlı olarak insanların ihtiyaç duydukları beceriler her geçen gün farklı bir boyut kazanmakta ve çeşitlenmektedir. 21. yüzyıl yaşam ve öğrenme becerileri olarak adlandırılan ve yaşamın anlamlandırılmasında sıkça kullanılan bu becerilerden birisi eleştirel dinleme/izlemedir. İnsanlar günlerinin önemli bir bölümünü dinleme/izleme faaliyeti içerisinde geçirmekte ve başta medya ve sosyal medya olmak üzere birçok elektronik kaynaktan yoğun ileti enformasyonuna maruz kalmaktadır. Bu durum insanların eleştirel bir tutum almasını zorunlu kılmaktadır. Bu bağlamda eleştirel dinleme/izleme kavram ve becerisi ön plana çıkmakta ve özellikle dil ve düşünme becerilerinin beraber ele alındığı Türkçe derslerinde bu becerinin öğrencilere kazandırılması gerekli olmaktadır. Bu çalışmada eleştirel dinleme/izleme kavramı anlam, işlev ve ilkeler yönüyle ele alınıp incelenmekte, alan yazında yeterli çalışmanın bulunmadığı kavram farklı boyutlarıyla tanıtılmaktadır. Ayrıca eleştirel dinlemenin/izlemenin öğretim süreci de ele alınmakta ve ortaokul Türkçe derslerindeki öğretimine yönelik bir çerçeve oluşturmaya çalışılmaktadır. Araştırmada Türkçe Öğretim Programlarında eleştirel dinlemenin/izlemenin hangi düzeyde yer aldığı tespit edilmekte ve kavramın Türkçe derslerindeki önemi vurgulanmaktadır. Bu bağlamda çalışmanın hem alan araştırmalarına hem de öğretmenlerin ortaokul düzeyinde gerçekleştirdiği eleştirel dinleme/izleme uygulamalarına katkı sunması beklenmektedir.

Anahtar kelimeler: Eleştirel dinleme/izleme, Türkçe dersi, öğretim süreci, beceri.

\section{The importance and place of critical listening/monitoring in Turkish education}

\begin{abstract}
It is an undeniable reality that our world, which is experiencing rapid changes in societies, is becaming more complex structure each day, changing the meaning attributed to science and changing the ways of reaching information. Accordingly, the skills that people need are gaining a different dimension and diversifying day by day. Critical listening / monitoring is one of these skills which is called 21st century life and learning skills and is used frequently in the meaning of life. People spend a significant of their day listening and watching, and are exposed to a lot of electronic information, especially media and social media. This situation requires people to take a critical attitude. In this context, critical listening / monitoring concept and skills come to the forefront and it is necessary for students to acquire this skill especially in Turkish courses where language and thinking skills are
\end{abstract} Uygulamaları Üzzerine Bir Eylem Araştırması" isimli doktora tezinin kuramsal çerçeve bölümünden hareketle üretilmiştir.

2 Dr. Öğr. Üyesi, Gaziantep Üniversitesi, Nizip Eğitim Fakültesi, Türkçe ve Sosyal Bilimler Eğitimi Bölümü (Gaziantep, Türkiye), cafer.carkit@gantep.edu.tr, ORCID ID: oooo-ooo3-4126-2165 [Makale kayıt tarihi: 03.08.2019-kabul tarihi: 20.09.2019; DOI: 10.29000/rumelide.618150] 


\begin{abstract}
handled together. In this study, the concept of critical listening / monitoring is examined in terms of meaning, function and principles, the concept that lack of sufficient studies in the literature is introduced with different dimensions. The process of teaching critical listening is also covered. Thus, it is tried to form a framework for teaching secondary school Turkish lessons. In this research, the level of critical listening / monitoring in Turkish Curriculum is determined and the importance of the concept in Turkish lessons is emphasized. In this context, the study is expected to contribute to both field research and the critical listening / monitoring practices of teachers at secondary level.
\end{abstract}

Keywords: Critical listening/monitoring, Turkish lesson, teaching process, skill.

\title{
Giriş
}

İnsanın içinde bulunduğu toplumla uyum içerisinde yaşamasında en sık kullandığı becerilerden biri dinlemedir. "Dinleme kişinin tercihine bağlı olarak, seçerek ve isteyerek algıladığı sesler bütünüdür" (Özbay, 2010, 49). Yani dinleme sürecinde birey etkin bir konumda bulunur. Mackay’a (1997) göre iyi bir dinleyici dinleme sürecinde sadece işittiklerine dikkat kesilmez aynı zamanda konuşmacının beden dili, konuşma hızı, ses tonu, sözcük seçimi gibi birçok uyarıcıya karşı duyarlı olur. Bu anlamda iyi bir dinleyici bir yandan işittiği sesleri anlamlandırma çabası gösterirken bir yandan da dinlediği içeriklere uygun tepkiler geliştirir. Böylece dinleyici süreçte pasif değil aktif bir konumda yer almış olur.

Dinleme iletişim sürecinde en sık kullanılan bir dil becerisidir. Bireyler gün içerisinde okul, ev, hastane, ulaşım araçları ve alış veriş gibi günlük aktivitelerini gerçekleştirdikleri ortamlarda ya da televizyon, telefon, tablet gibi sanal iletişim araçlarının karşısında dinleyici konumunda bulunurlar. "İletişim sürecinde \%40 dinleme, \%35 konuşma, \%16 okuma, \%9 yazma becerileri kullanılmaktadır” (BurleyAllen, 1995, s. 2). Bu durum dinlemenin bireylerin yaşamında ne kadar hayati bir yerinin olduğunu göstermesi bakımından önemli bulunmaktadır. Dinleme becerisini etkili bir şekilde kullanamayan insanların yaşamına anlaşma ve uzlaşı değil sürtüşme ve zaman zaman şiddete varan olumsuz davranışlar hâkim olur. Dinleme bireyler arasındaki bağı oluşturan temel unsurlardan bir tanesidir. "İnsanlar ancak bir başkası tarafindan dinlenirken kendilerini bulur ve kim olduklarını anlarlar" (Cüceloğlu, 2002, s. 137). Doğru ve sağlıklı bir iletişimin kurulup sürdürülebilmesi ancak etkili bir dinleme becerisi ile olur. "Kişisel ilişkilerin yanı sıra profesyonel gelişim için de dinleme becerisi kritik bir öneme sahiptir” (Brownell, 2016, s. 9). Günümüzde eğitimden sağllğa halkla ilişkilerden basın yayına kadar birçok meslek grubunun icrasında dinlemenin önemli bir yeri vardır.

Etkili dinlemenin gerçekleşebilmesi için dinleyicilerin çeşitli mikro yetilere sahip olması gerekmektedir. Çünkü dinleyiciler ancak bu yetiler aracıllğ̆ ile dinlediği/izlediği içerikleri anlamlandırır ve değerlendirir. Özellikle akademik dinleme/izleme sırasında kullanılan ve Richard (1983, s. 198) tarafından ifade edilen bu yetiler aşağıda maddeler hâlinde sunulmaktadır:

a. Konuşmanın amacını ve kapsamını belirlemek,

b. Konuşmanın konusunu belirleyip konu gelişimini takip etmek,

c. Konuşmada belirteçlerin (bağlaçlar, zarflar) rolünü fark etmek,

d. Dinlediklerinde ana fikir, yardımcı fikir, genelleme, örnekleme gibi ilişkileri tespit etmek,

e. Dinledikleri ile ilişkili anahtar sözcüleri belirlemek,

f. Bağlamdan hareketle kelimelerin anlamlarını çıkarmak,

g. Sözel olmayan ipuçlarını tanımak,

h. Neden sonuç amaç sonuç gibi anlamsal ilişkileri tespit etmek, 
i. Vurgu ve tonlamanın işlevini belirlemek

j. Konuşmacının konuya yönelik tutumunu tespit etmek,

k. Konuşma sürecinde gereksiz olan ifadeleri belirlemek,

Ortaya konulan bu mikro yetiler dinleme sürecinde dinlenen/izlenen içeriğe karşı eleştirel bir tutumun ortaya konulmasını sağlamaktadır. Çünkü içinde yaşadığımız çağda etkili bir dinleyici olmanın esaslarından biri eleştirel dinleme/izleme becerisine sahip olup onu günlük hayatta aktif olarak kullanmaktır. Küreselleşen dünyamızın her geçen gün daha karmaşı bir yapıya dönüşmesi, bilime yüklenen anlamın değişmesi ve bilgiye ulaşma yollarının boyut değiştirmesi inkâr edilemez bir gerçeklik olarak karşımızda durmaktadır. Modern birey bir dinleyici/izleyici kimliği ile başta medya ve sosyal medya olmak üzere birçok elektronik kaynaktan ileti bombardımanına maruz kalmaktadır. Yaşanan bu durum modern insanın eleştirel bir tutum almasını bir zorunluluk olarak karşımıza çıkarmaktadır. Bütün bunlar eleştirel dinleme/izleme kavram ve becerisini ön plana çlkarmakta ve özellikle dil ve düşünme becerilerinin beraber ele alındığı Türkçe derslerinde bu becerinin öğrencilere kazandırılmasını gerekli kılmaktadır. Bu anlamda eleştirel dinleme/izleme kavramının genel özellikleri, ilkeleri, temel unsurları ortaya konulmalı ayrıca Türkçe derslerinde bu kavramın nasıl yer aldığı ve öğretiminin hangi aşamalarda gerçekleştirileceği açık bir şekilde ortaya konulmalıdır.

\section{Çalışmanın amacı}

Türkçe dersleri hem dil hem de düşünme becerilerinin öğrencilere kazandırıldığı bir derstir. Bu anlamda temel dil becerilerine dönük gerçekleştirilecek etkinliklerde öğrencilerin düşünme yetilerinin de geliştirilmesi amaçlanmalıdır. Düşünmenin hayati bir öneme sahip olduğu günümüzde bu bir zorunluluk olarak karşımıza çıkmaktadır. Düşünmenin en temel boyutlarından biri eleştirel düşünmedir. Eleştirel bir bakış açısına sahip olmak çağımızda bireylerin sahip olması gereken esaslardan biridir. Çünkü günümüzde eleştirel bir tutuma sahip olmadan sağlıklı bilgilere ulaşıp doğru kararlar alabilmek oldukça zor görünmektedir. Bireylerin günlük hayatının önemli bir bölümünü dinleyerek/izleyerek geçirdiği göz önüne alınırsa onlara kazandırılacak olan eleştirel dinleme/izleme becerisinin hayatlarında çok önemli bir işlevinin olduğu inkâr edilemez. Bu çalışmanın temel amacı eleştirel dinleme/izleme kavramının anlam, işlev, ilkeler ve temel unsurlar yönüyle ele alınıp incelenmesidir. Böylece alan yazında yeterli çalışmanın bulunmadığı konunun farklı boyutlarıyla tanıtılıp ortaokul Türkçe derslerindeki öğretimine yönelik bir çerçeve oluşturulması amaçlanmaktadır. Böylece çalışmanın hem alan araştırmalarına hem de öğretmenlerin ortaokul düzeyinde gerçekleştirdiği eleştirel dinleme/izleme uygulamalarına katkı sunması beklenmektedir.

\section{Yöntem}

Araştırmada literatür taramasına bağlı olarak bir derleme çalışması yapılmaktadır. Öncelikle eleştirel dinleme/izleme becerisinin ne olup ne olmadığı üzerinde durulmakta ve konu farklı boyutları ile ele alınmaktadır. Daha sonra ise eleştirel dinleme/izleme becerisinin öğretim sürecine yönelik kuramsal bir çerçeve oluşturulmaktadır. 2006, 2015 ve 2018 Türkçe Dersi Öğretim Programlarında eleştirel dinleme/izleme becerisinin durumu doküman incelemesi ile tespit edilmekte ve bu beceriyle ilişkili kazanımlar sunulmaktadır. "Doküman incelemesi, araştırılması hedeflenen olgu veya olaylar hakkında bilgi içeren yazılı materyallerin analizini kapsar” (Yıldırım ve Şimşek, 2016, s.189). Dokümanlar nitel araştırmaların önemli kaynakları olarak görülür. "Araştırma problemine ilişkin olarak yazılı ve görsel dokümanların incelenmesi daha zengin ve kapsamlı bir çıkarım sağlanması açısından oldukça önemlidir" (Baş ve Akturan, 2016, s.140). Bu anlamda ilgili programların doküman analizi ile incelenmesi eleştirel dinleme/izleme becerisinin 
programlardaki görünümü ortaya koyması açısından önemli bulunmaktadır. Yıldırım ve Şimşek' e (2016, s. 190) göre doküman incelemesi tek başına bir veri toplama yöntemi olarak da diğer veri toplama yöntemleriyle birlikte de kullanılabilir. Bu araştırmada doküman incelemesi yapılan derleme çalışmasına katkı sunması yönüyle kullanılmıştır.

\section{Eleştirel dinleme/izleme nedir?}

Eleştirel dinleme/izleme günümüzde ihtiyaç duyulan temel becerilerden biridir. "Eleştirel dinleme, dinlediğimiz şeyin doğru olup olmadığını belirlemektir" (Yalçın, 2012, s. 134). Dinlenen/izlenen içeriklerin düşünce süzgecinden geçmesine olanak veren bu beceri ile konuşmacının ifade ettiği bilgilerin inanılırlık payı ortaya konulur. "Eleştirel dinleme/izleme, öğrencilere dinledikleri/izledikleri içeriklere yönelik soru sorma alışkanlığı kazandırarak konu hakkında düşünmelerini; konuyu olumlu ve olumsuz yönleriyle ve tarafsız bir bakış açısıyla değerlendirmelerini sağlayarak kendi doğrularını buldurmaktır" (MEB, 2006, s. 61-62). Bu anlamda eleştirel dinleme/izleme sürecinde dinleyici bir yandan konunun olumlu ve olumsuz yönlerine odaklanırken bir yandan da dinlediği/izlediği içeriklere yönelik bir sorgulama sürecine girer.

Eleştirel dinleme/izleme düşünme becerileri çerçevesinde gerçekleştirilen bir beceridir. Trace'e (2013) göre eleştirel dinleme gelişigüzel bir dinleme olmayıp üst bilişsel becerilerin kullanılarak dinleme sürecinin biçimlendirildiği bir yetidir; yeterlilik ifade eden bir süreç değil aksine performansa dayalı ve sürekli geliştirilebilir bir yapıdır. Eleştirel dinleme/izleme sürecinde konuşmacı bütün özellikleri ile ele alınıp amaç, tutarlılık, tarafsızlık gibi yönlerden değerlendirilir. Bu süreçte eleştirel dinleyici konuşmacının düşüncelerine tarafsız bir bakış açısıyla yaklaşır; ifade edilen görüşlerin kanıtlara mı genel geçer söylemlere mi dayandığını belirler; bunlarla beraber dinlediği/izlediği konuşmalarda veya içeriklerde ortaya konan görüşlere katılmasa bile onları bir saygı çerçevesinde dinler.

Eleştirel dinleme/izleme sunulan bilgi ve olguların doğruluğu ve güvenilirliği hakkında şüpheci yaklaşmayı gerekli kılar. Bu anlamda eleştirel dinleyici dinleyip izlediklerine analitik bakar onları bir değerlendirme süzgecinden geçirdikten sonra onlar hakkında bir hüküm verir ve bir yargıya ulaşır. Buna göre eleştirel dinleme/izleme sürecinde dinlenen/izlenen içeriklerin anlamlandırılıp ön bilgiler ile bütünleştirilmesinden öte bir zihinsel faaliyet gerçekleşir. Bu anlamda eleştirel dinlemenin dinleme becerisinin en gelişmiş biçimi olarak adlandırılması yanlış olmayacaktır (Trace, 2013). Dinleyicilerin/izleyicilerin sözcüklerin anlamlarından öteye geçebildikleri bir süreç olarak görülen eleştirel dinlemede/izlemede fikirlerin birleştirilmesi, tutarlılıklarının kontrol edilmesi ve sorgulanması gibi görevler dinleyiciler tarafından etkin bir şekilde yerine getirilir. Ayrıca konuşmacıların bakış açıları, tezleri ve başvurdukları konuşma teknikleri analitik bir bakış açısıyla sorgulanır.

Eleştirel dinleme/izleme; anlama, organize etme ve çıkarımda bulunma becerilerini içermesi yönüyle geniş bir yelpazede gerçekleşmekte ve Boyd'a (2005) göre günümüzde, dinleme anlayışının egemen modeli hâline gelmektedir. Sadece gerçeklerin öğrenilmesi ve bilgi edinilmesinde değil duygu ve deneyimlerin anlaşılmasında da dinlemenin önemli bir işlevi olduğundan eleştirel dinleme söylem analizi ve yorum gerektiren bir süreç olarak da değerlendirilmelidir. Bu anlamda eleştirel dinleyiciler anlamın yanında amaç, tutum, niyet gibi işaretleri de yorumlayabilmelidirler.

Eleştirel dinleme/izleme ortamlarında verilen mesajlar eleştirel dinleyiciler tarafından daima bir düşünme süzgecinden geçirilir. Bu anlamda hem alınan mesajların anlamlandırılması için çaba harcanır hem de mesajlarda yer alan ikna unsurları, propaganda ögeleri, öznel ve duygusal söylemler tespit edilir. 
Böylece verilen mesajların bir hamaset söylemi mi ya da tutarlı ve kanıtlara dayalı bir ifade birimi mi olduğu ortaya konulur. Ama bu süreçte asla saygısızlık yapılmaz ya da kişilerin düşüncelerini ortaya koymalarına engel olacak bir tutum takınılmaz. Bu anlamda eleştirel dinleyici/izleyici yaptığı işin ciddiyetinin farkındadır. Bu veriler ışığında eleştirel dinleme/izleme için gerekli olan ve alan yazında karşımıza çıkan temel kavramlar Tablo 1'de gösterilmektedir.

Tablo 1. Eleştirel Dinleme/İzleme Becerisine Yönelik Temel Kavramlar

\begin{tabular}{|l|l|}
\hline \multirow{5}{*}{ Beceri } & Alt Beceriler \\
\hline \multirow{5}{*}{ Eleştirel Dinleme/İzleme } & Analitik Bakma \\
\cline { 2 - 2 } & Organize Etme \\
\cline { 2 - 2 } & Soru Sorma \\
\cline { 2 - 2 } & Çıarım Yapma \\
\cline { 2 - 2 } & Yorumlama \\
\cline { 2 - 2 } & Yargıya Varma \\
\cline { 2 - 2 } & Değerlendirme \\
\hline
\end{tabular}

Eleştirel dinlemenin/izlemenin temel gereklerinden biri de ön yargllardan kurtulmaktır. Dinlediği/ izlediği içeriklere ön yargı ile yaklaşan bir dinleyicinin eleştirel bir bakış açısı ortaya koyup sağlıklı hükümler vermesi beklenemez. Dinleme/izleme ortamlarında aksan, saç şekli ve kıyafetler gibi uyarıcılar bir şekilde dinleyiciyi/izleyiciyi önceden etkileyip ön fikirler oluşturabilir. Bu durum karşısında yapılabilecek en doğru şey konuşmacının iletilerinden emin olana kadar herhangi bir değerlendirme yapmamaktır (Robertson, 2002). Bu bağlamda eleştirel dinleyici/izleyici ön yargılarından tamamen kurtulmalı ve nesnel bir tutum geliştirebilmelidir.

\section{Eleştirel dinleme/izleme ne değildir?}

Eleştirel sözcüğü dikkatli bir şekilde gözlem yapma, bir ölçüt bağlamında tenkit etme, bir durum karşısında şüpheci tutum alma gibi olumlu anlamlar taşıyabildiği gibi bir olay, olgu ya da durumun olumsuz yönlerini görme, kusur bulma veya hata arama gibi olumsuz anlamlar da yüklenebilmektedir (Paul \& Elder, 2013). Kelimenin olumsuz kullanımları eleştirel dinleme/izleme kavramının yanlış anlamlandırılmasına neden olabilir. Bu kullanımlar dinlenen/izlenen içeriklerde kusur arama ya da hata bulma anlamlarını çağrıştırabilir. Eleştirel dinleme/izleme kusur bulma, açık arama ve belirlenen eksiklerden hareketle konuşmacıya saldırarak dinleme/izleme ortamında olumsuz bir hava estirmek değildir. Eleştirel dinleyicinin/izleyicinin amacı asla konuşmacıyı rencide etmek değildir. Aksine eleştirel dinleyici/izleyici konuşmacının fikirlerine katılmasa bile onu saygı ile dinler ve fikirlerine, söylemlerine dikkat kesilir.

Eleştirel dinleyicinin/izleyicinin ifade edilen bütün görüşleri kabul etmesi veya reddetmesi düşünülemez. "Eleştirel dinleme toptan kabul veya toptan ret olmadığı gibi sürekli şüphecilik de değildir” (Doğan, 2013, s. 35). Eleştirel dinleyici/izleyici belli ölçütler çerçevesinde dinlediklerini/ izlediklerini ele alır ve nesnel bir tutumla bunları sorgular. Dinlediklerinde/izlediklerinde ortaya konulan kanıtlar olup olmadığına bakar.

Eleştirel dinleyici/izleyici dinlediği/izlediği içeriklere benmerkezci bir bakış açısı ile yaklaşmaz. Eleştirel dinleme/izleme asla benmerkezci bir dinleme değildir. Eleştirel dinleyicinin her şeyden önce kendisine özsaygısı vardır dolayısıyla o herkesi değerli görür. Buna bağlı olarak da dinlediklerine /izlediklerine 
değer verir. Düşüncelerini ifade ederken kırıcı ve yıkıcı bir üslup kullanmaz, nazik ve yapıcı bir üslup ile eleştirilerini ortaya koyar. Eleştirinin amacının muhatabını küçük düşürmek değil onun eksiklerini görüp bunları telafi etmesine katkı sunmak olduğunu bilir. Bu anlamda bütün davranışlarında bu ilke doğrultusunda hareket eder.

Eleştirel dinleme/izleme empatik dinlemeden/izlemeden uzaklaşıp konuşmacının duygularını bir kenara bırakmak demek değildir. Ĕger bir konuşmada duygular göz ardı edilirse dinlemede/izlemede büyük bir eksiklik oluşur. Duygular insan hayatına renk ve anlam katar; insanın belli amaçlar doğrultusunda yaşamasına olanak verir nihayetinde hayatın iyi ya da kötü yönlerinin anlamlandırılmasını sağlar (Robertson, 2002). Eleştirel dinleyici/izleyici her zaman bunun farkındadır. Buna rağmen o asla duygusallı̆̆n gerçekliğin önüne geçmesine izin vermez. Duygusallık ve gerçeklik arasındaki dengeyi sağlıklı bir şekilde kurar ve bunun iyi bir gözlemcisi ve takipçisi olur.

Eleştirel dinlemede/izlemede değerlendirme süreci sadece konuşmacının ya da sunulan içeriklerin değerlendirilmesini içermez. Yani eleştirel dinleyici/izleyici yalnızca muhatabını değerlendirmez. Eleştirel dinleyici/izleyici her şeyden önce dinleyip izlediklerinden hareketle öz değerlendirmesini yapabilmelidir. Çünkü eleştirel dinleme/izleme sürecinde öz değerlendirmenin çok önemli bir yeri vardır ve bireyler ancak öz değerlendirme yaparak entelektüel anlamda bir ilerleme ve gelişim gösterebilirler.

\section{Eleștirel dinlemenin/izlemenin temel ilkeleri}

Eleştirel dinleme/izleme belli kurallar doğrultusunda gerçekleşir. Eleştirel dinleyicinin/izleyicinin bu kuralları bilip ona göre hareket etmesi gerekmektedir. Tıpkı eleştirel düşünmede olduğu gibi eleştirel dinlemede/izlemede de belli ilkeler vardır. Eleştirel dinleyici/izleyici bu ilkeler doğrultusunda dinleme sürecine yön verir ve dinlediği/izlediği içerikleri bu bağlamda değerlendirir. Paul \& Elder'den (2013) hareketle eleştirel dinleme/izlemeye uyarlanan bu ilkeler aşağıdaki şekilde ifade edilebilir:

a. Düşünce özgürlüğü eleştirel dinleme/izleme için bir zorunluluktur.

b. Eleştirel dinleme/izleme ancak demokratik ortamlarda gerçekleşebilir.

c. Eleştirel dinleme/izleme adil ve nesnel bir tutum gerektirir.

d. Eleştirel dinlemede/izlemede entelektüel bir çabaya ihtiyaç vardır.

e. Eleştirel dinleme/izleme sistematik (sokratik) sorgulama ile gerçekleşir.

f. Eleştirel dinleme/izleme bir sabır işidir.

g. Eleştirel dinleme/izleme ön yargılardan tamamen uzaklaşmayı gerektirir.

h. Eleştirel dinleme/izleme insancıldır.

i. Eleştirel dinlemede/izlemede kendini geliştirmenin sınırı yoktur.

j. Eleştirel dinleme/izleme entelektüel cesaret gerektirir.

k. Eleştirel dinleme/izleme duygusallık ile gerçeklik arasında denge kurabilmeyi gerektirir.

$\mathrm{Bu}$ ilkeler eleştirel dinleyici/izleyici ve eleştirel dinleme/izleme eğitimi veren öğretmenler için yol gösterici konumdadır. Çünkü "çağdaş eleştiri anlayışı belli koşulları gerekli kılar” (İpşiroğlu, 2015, s. 86). Özellikle öğretmenlerin bu ilkeleri göz önünde bulundurmaları gerekmektedir çünkü eleştirel dinleme/izleme becerisi her şeyden önce demokratik öğrenme ortamlarında kazanılabilir. Öğretmenlerin sınıflarında bu ilkeler doğrultusunda öğretim yapmaları eleştirel dinleyiciler/izleyiciler yetiştirmek adına önemli ve gerekli bulunmaktadır. Otoritenin ve baskının yoğun bir şekilde hissedildiği öğrenme ortamlarında öğrencilerin eleştirel bir tutum takınmaları beklenemez. 
Eleştirel dinlemede/izlemede her zaman bir gelişim söz konusu olduğu için öğretmenlerin bu konuda sürekli sınıf içi pratikler yaptırmaları önemli görülmektedir. Çünkü hiç kimse hiçbir zaman ideal bir eleştirel dinleyici/izleyici olmayacaktır ve bu konuda her zaman bir derece söz konusudur. Öğretmenler bu süreçte öğrencilerine rol model olmalı; öğrencilerine eleştirel ve düşünsel konularda rehberlik etmelidirler.

\section{Türkçe dersi öğretim programlarında eleştirel dinleme/izleme becerisi}

Çalışmanın bu bölümünde yapılandırıcı yaklaşım doğrultusunda hazırlanan ve düşünme becerileri kavramlarına yer vermiş olan 2006, 2015 ve 2018 Türkçe Dersi Öğretim Programlarında eleştirel dinleme/izleme becerisinin hangi boyutları ile bulunduğu belirlenecektir. Bu programların kazanımları içerisinde eleştirel dinleme/izleme becerisi ile ilişkilendirilenler tespit edilecektir. Böylece eleştirel dinleme/izleme becerisinin ilgili programlardaki konumu ortaya konulacak ve Türkçe derslerindeki çerçevesi belirlenmeye çalışlacaktır.

\section{Türkçe Dersi Öğretim Programı'nda eleştirel dinleme/izleme becerisi}

2006 Türkçe Dersi Öğretim Programı'yla (6-8. Sınıflar) “dinlediklerini, izlediklerini ve okuduklarını anlayan; eleştirel ve yaratıcı düşünen, sorumluluk üstlenen, girişimci, olay, durum ve bilgileri kendi birikimlerinden hareketle araştırma, sorgulama, eleştirme ve yorumlamayı alışkanlık hâline getiren bireyler yetiştirilmesi hedeflenmiştir” (MEB, 2006, s. 3). Programdaki bu ifadede dinlediklerini /izlediklerini sorgulayan, eleştiren ve yorumlayan bireyler yetiştirilmek istendiği vurgulanmıştır. $\mathrm{Bu}$ yönüyle 2006 TDÖP'de doğrudan eleştirel dinleme/izleme alanına yönelik bir hedef "Programın Temel Yaklaşımları" içerisinde yer almıştır.

Eleştirel dinleme/izleme belli bir sorgulama kültürünü gerektirir. Çünkü dinlenen/izlenen bir içerik hakkında nesnel yargılara ancak doğru sorular aracılı̆̆ıyla ulaşılabilir. 2006 TDÖP'de öğrencilerin eleştirel dinleme/izleme sürecinde aşağıdaki sorular çerçevesinde dinledikleri/izledikleri içeriği ele almaları beklenmektedir (MEB, 2006, s. 63).
a. Konuşmacinın amacı nedir?
b. Konuşmacı konuyla ilgili yeterli bilgi ve birikime sahip mi?
c. Verilen bilgiler güncel ve geçerli midir?
d. Konu tarafsız bir bakış açısıyla mı ele alınıyor? Eleştiriler doğru mu?
e. Alternatif çözüm önerileri sunuluyor mu?
f. Çözüm önerileri bilimsel mi?

Programda "Eleştirel Dinleme/İzleme" başlığı altında yer alan bu ifadeler, programın eleştirel dinleyiciler/izleyiciler yetiştirmeyi önemli bir hedef olarak belirlediği ve Türkçe derslerinde buna özel bir yer verildiğini göstermesi bakımından önemli bulunmaktadır. Çünkü programda belirtilen bu sorular eleştirel dinleme/izleme sürecinin takip edildiği sistematik bir çerçeve oluşturmaktadır. 2006 TDÖP'de dinleme alanı kazanımları içerisinde eleştirel dinleme/izleme becerisine ilişkin kazanımlar yer almıştır. Tespit edilen bu kazanımlar aşağıda gösterilmiştir. Farklı sınıf düzeyinde tekrar eden kazanımlara ikinci kez yer verilmemiştir.

a. Dinlediklerinde/izlediklerinde sebep-sonuç ilişkilerini belirler.

b. Dinlediklerinde/izlediklerinde amaç-sonuç ilişkilerini belirler.

c. Dinlediklerindeki/izlediklerindeki örtülü anlamları bulur. 
d. Dinlediklerine/izlediklerine ilişkin sorular oluşturur.

e. Dinlediklerinde/izlediklerinde yer alan öznel ve nesnel yargıları ayırt eder.

f. Dinlediklerine/izlediklerine ilişkin karşlaştırmalar yapar.

g. Kendisini şahıs ve varlık kadrosunun yerine koyarak olayları, duygu, düşünce ve hayalleri yorumlar.

h. Dinlediklerinin/izlediklerinin başlığı/adı ile içeriği arasındaki ilişkiyi ortaya koyar.

i. Görsel/işitsel unsurlarla dinledikleri/izledikleri arasında ilgi kurar.

j. Dinlediklerini/izlediklerini kendi hayatı ve günlük hayatla karşılaştırır.

k. Dinlediklerini/izlediklerini dil ve anlatım yönünden değerlendirir.

l. Dinlediklerini/izlediklerini içerik yönünden değerlendirir.

m. Dinlediği/izlediği kişiyi sesini ve beden dilini etkili kullanma yönünden değerlendirir.

Kazanımlar genel olarak incelendiğinde sorgulama, ilişki kurma, karşılaştırma ve değerlendirme gibi üst düzey düşünme becerilerini içermekte ve öğrencilerin dinlenen/izlenen içeriği eleştirel bir tutumla ele almalarını amaçlamaktadır. Bu yönüyle 2006 TDÖP'de eleştirel dinleme/izleme becerisinin dinleme alanında içerisinde önemli bir yerinin olduğu ifade edilebilir.

\section{Türkçe Dersi Öğretim Programı’nda eleştirel dinleme/izleme becerisi}

2015 TDÖP'de 2006 TDÖP'den farklı olarak “Dinleme/İzleme Yöntem ve Teknikleri” bölümüne yer verilmemiştir. Dolayısıyla eleştirel dinleme/izleme bir bölüm olarak programda yer almamıştır. 9 yıl yürürlükte olan 2006 TDÖP’nin açıllayıcı bir yapısının olması ve programın sadeleştirilmek istenmesi bunun sebebi olarak gösterilebilir. 2015 TDÖP'de dinleme becerisine yönelik kazanımlar "Sözlü İletişim” başlığı altında ve 1-8. Sinıflar olmak üzere bütün sınıf düzeylerinde ele alınmıştır. Dinleme kazanımları içerisinde yer alan ve eleştirel dinleme/izleme ile ilişkilendirilen kazanımlar aşağıda gösterilmiştir. Farklı sınıf düzeyinde tekrar eden kazanımlara ikinci kez yer verilmemiştir.

a. Dinlediklerindeki/izlediklerindeki ana fikri ve ana fikri destekleyen düşünceleri belirler.

b. Dinlediklerini/izlediklerini ön bilgileriyle karşlaştırır.

c. Dinledikleriyle/izledikleriyle ilgili çıkarımlar yapar. (Neden-sonuç, amaç-sonuç, karşılaştırma, benzetme, örneklendirme, duygu belirten ifadeler, abartma, nesnel ve öznel çıkarımlar vb. üzerinde durulur.)

d. Dinledikleri/izledikleriyle ilgili görüşlerini mantıksal sıra içerisinde açıklar.

e. Konuşmacının tezlerinden ve görüşlerinden hangilerinin gerekçeler ve kanıtlarla desteklendiğini, hangilerinin desteklenmediğini ayırt eder.

f. Dinlediklerindeki/izlediklerindeki bilgi ve düşüncelerin tutarlılığını sorgular.

g. Dinlediklerinde gerçek ve kurgu olanı ayırt eder.

h. Dinlediği konuşmada öne sürülen düşüncelerin gerekçelerini ve kanıtlarını belirler.

i. Dinlediği konuşmada öne sürülen düşüncelerin gerekçelerini ve kanıtlarını belirler, sorgular ve değerlendirir.

j. Dinlediği/izlediği bir metnin, medya içeriğinin veya sözel sunumun örtülü anlamını belirler.

2015 TDÖP’nin eleştirel dinleme/izleme ile ilişkilendirilen kazanımları incelendiğinde bu kazanımlarla öğrencilerin dinledikleri/izledikleri düşünce veya bilgilerin tutarlı olup olmadığını sorgulamaları; dinlediği bir konuşmada ifade edilen fikirlerin gerekçe ve kanıtlarını belirlemeleri, sorgulamaları ve değerlendirmeleri beklenmektedir. Ayrıca kurgu ile gerçeği ayırt edebilmeleri, dinledikleri/izledikleri içerikleri ön bilgileri ile karşılaştırabilmeleri ve dinlediklerine/izlediklerine dair çıkarımlar 
yapabilmeleri öğrencilerin kazanmalarının amaçlandığı önemli eleştirel dinleme/izleme kazanımlarıdır. Bunlarla beraber medya içeriğine yönelik örtülü anlamın belirlenmesine ilişkin kazanım eleştirel dinlemenin/izlemenin medya boyutuyla programda yer aldığını göstermesi bakımından önemli görülmektedir.

\section{Türkçe Dersi Öğretim Programı’nda eleştirel dinleme/izleme becerisi}

2015 TDÖP’de dinleme ve konuşma becerileri birleştirilerek ‘Sözlü Anlatım' başlı̆̆ı altında yer almıştır. Böylece dinleme ve konuşma becerileri sözlü anlatım alanında değerlendirilmekteydi. 2018 TDÖP’de bu anlayıştan vaz geçildiği görülmektedir. Programın kazanımları "dinleme/izleme, konuşma, okuma ve yazma becerilerine göre gruplandırılarak sınıf düzeylerine göre farklı başlıklar altında verilmiştir" (MEB, 2018, s.20). Bu bağlamda programın kazanımlarının gruplandırılmasında 2006 TDÖP yaklaşımının esas alındığı ifade edilebilir.

2018 TDÖP'de tüm sınıf düzeylerinde eleştirel dinleme/izleme becerisine yönelik kazanımlara yer verilmiştir. Programda özellikle soyut düşünme becerisinin edinildiği 7 ve 8 . Sinıf düzeylerinde medya içeriklerinin eleştirel bir bakış açısıyla ele alınması beklenmektedir. Böylece öğrencilerin Türkçe derslerinde edindikleri eleştirel dinleme/izleme becerisini günlük hayatlarına aktarmaları ve medyanın yoğun ileti bombardımanı karşısında eleştirel bir tutum alabilmeleri amaçlanmıştır. Programda belirlenen eleştirel dinleme/izleme ile ilişkilendirilen kazanımlar aşağıya alınmıştır. Farklı sınıf düzeylerinde tekrar eden kazanımlara ikinci defa yer verilmemiştir.

a. Dinlediklerinin/izlediklerinin ana fikrini/ana duygusunu belirler.

b. Dinledikleriyle/izledikleriyle ilgili görüşlerini bildirir.

c. Konuşmacının sözlü olmayan mesajlarını kavrar.

d. Dinlediklerinin/izlediklerinin içeriğini değerlendirir.

e. Dinlediklerinde/izlediklerinde tutarlılığı sorgular.

f. Dinledikleri/izledikleri medya metinlerini değerlendirir.

2018 TDÖP ile öğrencilere dinlenen/izlenen içeriklerde sözlü olmayan iletilerin belirlenmesi, bu içeriklerin tutarlılığının sorgulanması ve değerlendirilmesi, dinledikleri/izledikleri ile ilgili görüşlerinin ortaya konulması gibi eleştirel dinleme/izleme becerilerinin kazandırılması amaçlanmaktadır. Program bu anlamda 2015 TDÖP ile benzerlik göstermektedir. Buna rağmen programın bütün kazanımlarında olduğu gibi eleştirel dinleme/izleme kazanımlarında da bir azalma görülmektedir. Programların genel seyrine bakıldığında kazanım sayılarında bir azalma olduğu görülmektedir. 2006 TDÖP'de 13 olan eleştirel dinleme/izleme kazanım sayısı 2015 TDÖP'de 102018 TDÖP'de 6 olarak tespit edilmiştir. Bu durum yıllar içerisinde TDÖP’lerin sadeleştirilmesi yönünde çalışmalar yapıldığını göstermektedir.

\section{Eleştirel dinleme/izleme becerisinin öğretimi}

Eleştirel dinleme/izleme becerisinin öğretim uygulamaları eleştirel düşünme ile paralel bir süreçte meydana gelmektedir. Her iki becerinin de öğretimi uzun bir süreç gerektirmektedir. Eleştirel dinleme/izleme uygulamaları ile öğrencilerin hem dinleme hem de düşünme becerilerinin geliştirilmesi amaçlanmalıdır. Öğrenme ortamlarının hazırlanmasında öğrencilerin ilgileri ile birlikte hedef kazanımlar dikkate alınmalıdır. Boyd (2005) öğretmenlerin öğrencilere eleştirel dinleme/izleme becerisi kazandırabilmelerinin yolunun sunuş yönteminin ötesine geçmeleri olduğunu ifade etmektedir. Eleştirel dinleme/izleme becerisi kısa yoldan öğrencilere kazandırılabilecek bir beceri değildir. Bunun 
için uygun ve yeterli bir zaman diliminde etkili, öğrenci merkezli ve uygulamaya dayalı bir eğitim gereklidir. Araştırmada eleştirel dinleme/izleme becerisinin öğretimi eleştirel dinleme/izleme öncesi, sırası ve sonrası olmak üzere üç aşamada ele alınmaktadır.

\section{Eleştirel dinleme/izleme öncesi}

Eleştirel dinleme/izleme öğretimine yönelik hazırlık çalışmalarının yapıldığı bölümdür. "Bu bölümde amaç belirleme, ön bilgileri harekete geçirme, anahtar kavramlarla çalışma gibi etkinlikler yapılır" (Güneş, 2007, s.87). Bu aşamada öğretmenler öğrencilerini hem duyuşsal hem de bilişsel ve fiziksel olarak eleştirel dinleme/izlemeye hazırlamalıdır. Buna göre eleştirel dinleme/izleme öncesi öğretmenlerin gerçekleştirebilecekleri etkinlikler aşağıya alınmıştır:

\section{Amaç belirleme}

Türkçe derslerinde eleştirel dinleme/izleme uygulamaları belli amaçlar çerçevesinde gerçekleştirilir. Eğitimde amaç kişiye kazandırılmak istenen bilgi, beceri, değer, ilgi, tutum gibi özellikler olarak tanımlanmaktadır (Sönmez, 2014, s. 17). Bir ders programında amaç "niçin" sorusuna karşllık gelir. Bu anlamda öğrenciler eleştirel dinleme izleme sürecinden önce dinleme/izleme içeriğini niçin dinleyeceklerini/izleyeceklerini sorgulamaya yönelik çalışmalar yapmalı ve amaçlarını açık bir şekilde ortaya koymalıdırlar. Öğretmenler bu aşamada soru cevap tekniği ya da beyin firtınası gibi tekniklerle öğrencilerin amaçlarını belirlemelerinde yol gösterici olmalıdırlar.

\section{Ön bilgileri harekete geçirme}

Günümüzde Türkçe dersleri yapılandırmacı yaklaşım doğrultusunda hazırlanan 2018 TDÖP çerçevesinde yürütülmektedir. Bu yaklaşımda "öğrencilerin ön bilgileri ve edinmiş oldukları deneyimler oldukça önem taşımaktadır” (Kabadayı ve Bozkurt, 2015, s.219). Eleştirel dinleme/izleme sürecinde öğrenciler dinleyip izledikleri içerikleri ön bilgileri ile anlamlandırırlar. Bu nedenle eleştirel bu süreçten önce öğrencilere konuyla ilgili ön bilgilerini hatırlatmak yararlı olacaktır. Öğretmenler bu aşamada günlük hayatla ilişkilendirilecek sorular veya örnek durumlarla öğrencilerin ön bilgilerini harekete geçirebilirler.

\section{Anahtar kavramlarla çahşma}

Anahtar kavramlar metinde yer alan ve özel öneme sahip olan kelimeleri karşılar (Güneş, 2014, s. 98). Eleştirel dinleme/izleme sürecinde anahtar kavramlar özel bir önem taşımaktadır. Hem öğrencilerin kelime hazinelerinin geliştirilmesi hem de dinlenecek/izlenecek içeriklerin öğrencilerde meydana getireceği çağrışımları belirlemek için bu kavramlar ile çalışmalar yapmak önemli bulunmaktadır. Öğrenciler bu aşamada çalışllan kavramlar bağlamında dinlenen/izlenen içeriğin çözümlemesini yapacaklardır. Bunun yanında bu bölümde eleştirel dinleme/izleme kavramlarının üzerinde durulması sürecin öğrenciler tarafından daha kolay anlaşılmasına da katkı sağlayacaktır.

\section{Ön yargzları fark etme}

Ön yargı eleştirel dinlemenin/izlemenin önündeki en büyük bariyerlerden biridir. "Bir kimseyle ya da şeyle ilgili olarak, belirli bir olaya, duruma ya da görmeye dayanan, önceden edinilmiş olumlu ya da olumsuz yargı, kanı" (TDK, 2005, s. 1856) olarak tanımlanan ön yargı bireylerin dinlenen/izlenen içeriğe karşı eleştirel bir tutum almalarını engellemektedir. Bu nedenle öğretmenler eleştirel dinleme/izleme 
sürecinden önce öğrencilerin ön yargılarını fark etmelerini sağlayacak etkinlikler yaptırmalıdır. Böylece öğrencilerin yanlı bir dinleme süreci gerçekleştirmelerinin önüne geçmelidir.

\section{Eleştirel dinleme izleme sırası}

Eleştirel dinleme/izleme sırasında dinlenen/izlenen içeriklere yönelik anlamlandırma, analiz etme, sorgulama, karşılaştırma gibi üst düzey düşünme becerileri işe koşulur. Bu aşamada öğretmenlerden öğrencilerin dinlenen/izlenen içerikleri eleştirel bir bakış açısıyla değerlendirebilmeleri için gerekli rehberlik çalışmalarını yürütmeleri beklenmektedir. Bunun için belli strateji ve tekniklerin kullanılması gerekmektedir. Bu aşamada yararlanılabilecek belli başlı strateji ve teknikler aşağıya alınmıştır.

\section{Not alma}

Dinlenen/izlenen içeriğin organize edilmesini ve öğrencilerin dikkatini dinlenen/izlenen içerik üzerinde toplanmasını sağlayan not alma eleştirel dinleme/izleme sürecinde başvurulacak önemli bir stratejidir. İyi bir dinleyicinin en önemli özelliği not almak için kalem ve kâğıdının daima hazır olmasıdır (Altun, 2012). Bu anlamda eleştirel dinleme/izleme sürecinde not tutmanın önemi öğrencilere anlatılmalıdır. "Öğrencilerin dinleme anında not almaları kendi başlarına edinebilecekleri bir beceri olarak görülmemelidir” (Özbay, 2010, 121). Bu çerçevede eleştirel dinleme/izleme sürecinde öğrencilerin dinlenen/izlenen içerikler üzerine notlar almalarına olanak tanıyan uygulamalar gerçekleştirilmelidir. Öğretmenler bu konuda öğrencilerine rehberlik etmeli, aldıkları notları ile rol model olmalıdır. Unutulmamalıdır ki not almak derse aktif katılımı sağlayan önemli bir yoldur. Baltaş’a (1999, s. 42) göre ise not almak ile iyi bir dinleyici olmak ele ele gitmektedir. Eleştirel dinleme/izleme sırasında alınan ve sözlü ve sözsüz ipuçlarını yansıtan notlar içeriğin eleştirel düzeyde anlamlandırılmasında öğrencilere önemli katkılar sağlamaktadır.

\section{Organize etme}

Eleştirel dinleme/izleme sırasında alınan notlardan hareketle dinlenen/izlenen içeriğin bir bütünlük oluşturacak şekilde organize edilmesi konunun yapısının çözümlenip değerlendirilmesine imkân tanır. Bu yapılar zıtlık, karşılaştırma, sebep-sonuç ve problem-çözüm ilişkisi bağlamında organize edilebilir (Tompkins, 2005, s. 312). Bu bağlamda eleştirel dinleme/izleme sırasında öğrencilerin dinlenen içerikleri bu yapılar bağlamında organize edebilmeleri için öncelikle bu kavramları bilmeleri ve bu çerçevede hazırlanmış etkinliklerle pratikler yapmaları gerekir. Öğretmenler hazırladıkları eleştirel dinleme/izleme etkinlikleriyle öğrencilerin bu stratejiyi etkili bir şekilde kullanmalarına olanak sunmalıdır.

\section{Sorgulama}

Eleştirel dinleme/izleme sırasında kullanılacak temel stratejilerden biri sorgulamadır. Bohlken'e (2000) göre eleştirel dinleyici, mesajın kaynağını, kaynağın özgünlüğünü, kaynağın verdiği bilgileri ve bağlamı (gerçek ve sözlü), bağlamın sözdizimini, ifadenin şu an geçerli olup olmadığını sorgulamalıdır. Dinlenen/izlenen içeriklerde olayların gelişme süreci, kahramanların karakter özellikleri, reklamların doğruluk ve güvenilirlik payları, konuşmalarda kullanılan ikna yöntemleri ve propaganda teknikleri eleştirel dinleyiciler/izleyiciler tarafından daima sorgulama sürecine tabi tutulmalıdır. Öğretmenler öğrenme ortamlarında buna zemin hazırlamalı ve öğrencilerini bu konuda cesaretlendirmelidirler. 

a. Düşün (Think)
b. Nedenini Sor (Ask why)
c. Niçin Dinlediğini Sor (Listen for what)
d. Kendine Anlat (Say to self)

Swain, Friehe ve Harrington (2004; akt. Ungan, 2007) yukardaki şekliyle ifade ettikleri (TALS) stratejiler ile dinlemenin daha etkili gerçekleşeceğini belirtmişlerdir. Bu stratejiler eleştirel dinleme/izleme sırasında da kullanılabilir. Dinlenen/izlenen içeriklerin sorgulanması bağlamında bu stratejiler oldukça etkilidir çünkü bunlar doğrudan öğrencilerin dinledikleri/izledikleri içerikler üzerine düşünmelerine ve bunların nedenlerini sorgulamalarına olanak tanımaktadır. Ayrıca bu stratejiler eleştirel dinleme/izleme sürecine aktif katılımı sağlamaları yönüyle de önemli görülmektedir.

\section{Eleştirel dinleme/izleme sonrası}

Eleştirel dinleme/izleme uygulamalarından sonra genel olarak değerlendirme çalışmaları yapılmalıdır. $\mathrm{Bu}$ çerçevede konuşmacının amacı ve tutumu, dinleme esnasında ortaya konulan görüşlerin tutarlılı̆̆ ve nesnelliği, dinlenen/izlenen içerikte kullanılan dil ve üslup dinleme/izleme sonrasında değerlendirme konusu yapılmalıdır. "Bu süreçte elde edilen verilerin duygular karıştırılmadan mantıksal olarak değerlendirilmesinin yapılması gerektiği vurgulanmalıdır” (Özden, 2014, 163). Yapılandırmacı yaklaşımda süreç değerlendirme ile öz değerlendirme kavramları ön plana çıkmaktadır (Arslan, 2009, 147). Bu nedenle eleştirel dinleme/izleme faaliyetlerinden sonra öğrencilerin öğrenme sürecini gözden geçirmeleri ve öz değerlendirmelerini yapmalarına da ortam hazırlanmalıdır.

\section{Sonuç}

Bir ihtiyaç olarak görülen eleştirel dinleme/izleme günümüzde öğrencilere kazandırılması gereken önemli bir yaşam ve öğrenme becerisidir. Aytan'a (2016) göre Türkçe derslerinde öğrencilere kazandırılacak olan eleştirel bakış, akademik başarı ve tutum açısından diğeri dersleri de olumlu etkileyecektir. $\mathrm{Bu}$ anlamda eleştirel dinleme/izleme öğrencilerin eleştirel düşünme becerisi kazanmalarına hizmet eden önemli bir süreçtir. "Eleştirel düşünmenin temeli olan eleştirel dinleme seçici dinlemeyi ve dinlenilenlerin değerlendirilmesini gerektirir" (Kemiksiz, 2015, s. 314). Bu sürecin en önemli özelliklerinden biri dinleyicinin/izleyicinin nesnel bir tutum alması ve dinleyip izlediği içerikleri ön yargı ve duygusallıktan uzak bir şekilde değerlendirmesidir. Eleştirel dinleme/izleme her ne kadar mantıksal bir süreçte gerçekleşse de empatiden uzaklaşmak değildir. Eleştirel dinleme/izleme duygular ile gerçeklik arasında denge kurabilmektir.

Türkçe derslerinin eleştirel dinleme/izleme becerisinin öğrencilere kazandırılmasında oldukça önemli bir yeri vardır. 2006, 2015 ve 2018 TDÖP'lerin tamamında eleştirel dinleme/izleme becerisi yer almıştır. $\mathrm{Bu}$ programların dinleme alanında yer alan kazanımlarının içerisinde eleştirel dinleme/izleme kazanımları da bulunmaktadır. Bu kazanımlarla öğrencilerden dinleyip izledikleri içerikleri sorgulamaları ve onları eleştirel bir bakış açısıyla değerlendirmeleri beklenmektedir. Aytan (2016) yaptığı çalışmada 2006 ve 2015 TDÖP’leri eleştirel düşünme bağlamında değerlendirmiş ve eleştirel düşünmenin kazandırılması bağlamında 2006 TDÖP'nin metodolojik olarak 2015 TDÖP'nin ise kazanımlar bakımından zengin olduğunu ifade etmiştir. Eleştirel dinleme/izleme açısından bakıldığında 
2006 TDÖP’nin 2015 ve 2018 TDÖP’lere göre kazanım ve sayısı ve dinleme/izleme yöntem ve tekniklerine yer vermesi açılarından daha zengin olduğu ifade edilebilir.

Eleştirel dinleme/izleme becerisinin öğretimi belli aşamalarda gerçekleşir. Eleştirel dinleme/izleme öncesi, sırası ve sonrası olarak isimlendirilebilecek bu aşamalarda öğretmenlerin belli strateji ve teknikler kullanmaları becerinin etkili bir şekilde öğrencilere kazandırılabilmesi için önemli bulunmaktadır. Buna göre eleştirel dinleme/izleme öncesi amaç belirleme, ön bilgileri harekete geçirme, anahtar kavramlarla çalışma ve ön yargıları fark etmeye dönük çalışmalar yapılabilir. Eleştirel dinleme/izleme sırasında, not alma, organize etme, sorgulama ve TALS stratejileri kullanılabilir. Eleştirel dinleme sonrasında ise değerlendirme faaliyetleri yapılmalıdır.

\section{Kaynakça}

Altun, K. (2012). Sözlü anlatım. (Edt. Kaçalin, M., Örgen, E., Altun, K.) Yazılı ve sözlü anlatım. Ankara: Elhan Kitap.

Arslan, A. (2009). Yapılandırmacı öğrenme yaklaşımı ve Türkçe öğretimi. Atatürk Üniversitesi Sosyal Bilimler Enstitüsü Dergisi, 13 (1), 143-154.

Aytan, T (2016). Evaluation of the 2006 and 2015 Turkish Education Program in Secondary School Curriculum in Turkey in Terms of Critical Thinking. Journal of Education and Learning, 5 (2), $38-46$.

Baş, T. ve Akturan, U. (2017). Sosyal Bilimlerde Bilgisayar Destekli Nitel Araştırma Yöntemleri (3. Baskı). Ankara: Seçkin Yayıncılık.

Bohlken, B. (2000). Training citizens in a democratic society to listen critically. International Listening Association. Virginia Beach, VA.

Baltaş, A. (1999). Öğrenme ve sınavlarda üstün başarı. İstanbul: Remzi Kitabevi.

Boyd, F. A.(2005). Critical listening. ANUPI. 1-12.

Brownell, J. (2016). Listening: attitudes, principles and skills. New York: Routledge.

Burley-Allen, M. (1995). Listening: the forgotten skill. New York: John Wiley \& Sons

Cüceloğlu, D. (2002). İletişim donanımları. İstanbul: Remzi Kitabevi.

Doğan, Y. (2013). Dinleme eğitimi. Ankara: Pegem Akademi.

Güneş, F. (2007). Türkçe öğretimi ve zihinsel yapılandırma. Ankara: Nobel Yayınları.

Güneş, F. (2014). Türkçe öğretimi yaklaşımlar ve modeller. Ankara: Pegem Akademi.

İpşiroğu, Z. (2015). Düşünmeyi öğrenme ve öğretme (5. baskı). İstanbul: Say Yayınevi

Kabadayı, A ve Bozkurt, E. (2015). Okul öncesi öğretmenlerinin yapılandırmacı yaklaşım ile ilgili yeterlilik düzeylerinin incelenmesi. Eğitim ve Öğretim Araştırmaları Dergisi, 4 (2), 218-225.

Kemiksiz, Ö. (2015). Türkçe öğretiminde eleştirel dinleme. Erzincan Üniversitesi Sosyal Bilimler Enstitüsü Dergisi, II, 299-316.

Mackay, I. (1997). Dinleme becerisi (Çev. Aksu, B. ve Onur, C.). Ankara: İlkkaynak Kültür ve Sanat Yayınları.

MEB (2006). İlköğretim Türkçe dersi (6, 7, 8. sınıflar) öğretim programı. Ankara: MEB Yayınevi.

MEB (2015). Türkçe dersi (1-8. sınıflar) öğretim programı. Ankara: MEB Yayınevi.

MEB (2018). Türkçe dersi (1-8. sınıflar) öğretim programı. Ankara: MEB Yayınevi

Özbay, M. (2010). Anlama teknikleri II: Dinleme eğitimi. Ankara: Öncü Kitap.

Özden, Y. (2014). Öğrenme ve öğretme. Ankara: Pegem Akademi. 
Paul, R., Elder, L. (2013). Kritik düşünce. (Çev. Aslan, A.E, Sart, G.). Ankara: Nobel Yayınları.

Richards, J. C., (1983). Listening comprehension: Approach, design, procedure. TESOL Quarterly, 17, 219-238.

Robertson, A. K.(2002). Etkili dinleme. (Çev.Yarmalı, E. S.) İstanbul:Hayat Yayınları.

Sönmez, V. (2014) Öğretim ilke yöntemleri (7. baskı). Ankara: Anı yayıncılık.

TDK (2005). Türkçe sözlük. Ankara: Türk Dil Kurumu Yayınları.

Tompkins, G. E. (2005). Language arts: Patterns of practic. New Jersey: Pearsone- PrenticeHall

Trace, J. (2013). Designing a task based critical listening construct for listening assessment. Second Language Studies, 32(1), 59-111.

Ungan, S. (2007). Dinleme eğitimi. (Edt. A. Kırkkılıç ve H. Akyol). İlköğretimde Türkçe öğretimi. Ankara: PegemA Yayıncilık, s. 148-163.

Yalçın, A. (2012). Türkçe öğretim yöntemleri. Ankara: Akçă̆ Yayınları.

Yıldırım, A. ve Şimşek, H. (2016). Sosyal bilimlerde nitel araştırma yöntemleri (10. Baskı). Ankara: Seçkin Yayıncıllk. 